\title{
A Study of Folate Absorption and Metabolism in Man Utilizing Carbon-14-Labeled Polyglutamates Synthesized by the Solid Phase Method
}

\author{
C. E. Butterworth, Jr., C. M. Baugh, and Carlos Krummieck \\ From the Division of Nutrition, Department of Medicine, Medical College of \\ Alabama, Birmingham, Alabama 35233
}

A B S T R A C T The absorption and metabolism of synthetic polyglutamates of folic acid have been compared with free pteroylglutamic acid in four subjects having chronic lymphatic leukemia and one with Hodgkin's granuloma. Pteroylpolyglutamates containing either three or seven glutamate residues were prepared by the solid-phase method permitting placement of carbon-14 labels in either the pteridine ring or in a selected glutamate unit of the gamma peptide chain. Complete dissociation was observed between biological folate activity and radioactivity of plasma after ingestion of pteroyltriglutamate labeled in the middle glutamate. This indicates cleavage to the monoglutamate form at the time of absorption from the intestine or very soon thereafter. A large portion of radioactivity liberated from the middle glutamate is recoverable as carbon dioxide in the exhaled air.

Fecal losses of folate tended to be greater with increasing length of the poly- $\gamma$-glutamyl chain. Higher blood levels and greater urinary losses of folate tended to occur after ingestion of mono- and triglutamates than with the heptaglutamate. Calculations based on radioactivity determinations in feces plus urinary folate losses, judged by either radioactivity or microbiological assays, indicated net retention of $37-67 \%$ of the dose irrespective of chain length ingested and major avenue of loss.

During the peak of absorption the folate circulating in plasma was active for both Streptococcus fecalis and Lactobacillus casei and carried specific radioactivity which was virtually identical with that of the administered dose. This suggests that neither methylation, conjugation, nor displacement of nonradioactive folate occurred to any significant extent during the 1 st $2 \mathrm{hr}$. The specific radioactivity of $24-\mathrm{hr}$ urine specimens as measured with $L$. casei corresponded closely with that of the administered dose. Evidence exists that methyla-

Received for publication 10 January 1969. tion of the radioactive folate may occur, but significant displacement of nonradioactive methylfolate was not observed under the conditions of this study. Since $50-75 \%$ of administered heptaglutamate appears to be absorbable in man, estimates of dietary intake should include this fraction as well as the "free" folate.

\section{INTRODUCTION}

Even before the chemical structure of folic acid was established it was recognized that yeast folate is inactive in microbiological assay systems but quite active as a dietary supplement in the chick assay system (1). Since previous treatment with suitable digestive enzymes yielded a product which was active in both types of assay, the yeast folate was referred to as "vitamin $B_{c}$-conjugate," and the splitting enzyme was referred to as conjugase (2). Subsequently it was found that the folate of yeast is a conjugate of pteroic acid with seven molecules of glutamic acid in a gamma peptide chain (3), while the folate derived from bacterial fermentation has three gamma glutamyl units (4). These observations suggest that the polyglutamyl side chain is a key factor in the ability of cells to absorb and utilize folate. It is well known that a large portion of the folate in foods consumed by man exists in the polyglutamate form (5-7). It has not been possible until now to carry out a systematic evaluation of the digestion, absorption, and availability to man of folylpolyglutamates. The principal reason has been the lack of test materials of known structure and purity, with suitable radioactive labels. Recently the solid-phase procedure for the synthesis of alpha peptides, as described by Merrifield (8), has been adapted to permit the unambiguous synthesis of gammaglutamyl peptides of each chain length from two to seven. When one of these chains is coupled to pteroic acid, a folylpolyglutamate of known structure is pro- 
duced. Similarly it has been possible to introduce glutamic acid-uniformly labeled ${ }^{14} \mathrm{C}$ (glutamic acid-UL- ${ }^{14} \mathrm{C}$ ) units at selected positions in the side chain or to couple with pteroic acid bearing an atom of ${ }^{14} \mathrm{C}$ in the pteridine ring. By combining microbiological assay techniques and radioactivity measurements, it is now feasible to examine more accurately the patterns of folylpolyglutamate absorption and metabolism in man. The purpose of this paper is to present our findings in five human subjects after the oral ingestion of either folic acid or folylpolyglutamates suitably labeled with ${ }^{14} \mathrm{C}$ in either the pteridine ring or in one of the glutamyl residues.

\section{METHODS}

The clinical studies involved four patients with chronic lymphatic leukemia and one with Hodgkin's granuloma. The patient with Hodgkin's disease was in a state of complete remission, having no evidence of lymphomatous masses, fever, or hematologic abnormality. Three of the chronic lymphatic leukemia subjects were asymptomatic and in partial remission having no anemia, and their white blood cell counts ranged from 12,100 to $27,500 / \mathrm{mm}^{3}$. Therapy with chlorambucil was omitted at least 1 wk before study. A fourth patient had untreated chronic lymphatic leukemia, a total leucocyte count of $139,000 / \mathrm{mm}^{3}$, and a hematocrit of $31 \%$. All leukemia subjects had palpable lymph nodes and mild to moderate hepatosplenomegaly. All five subjects were demonstrated to have normal intestinal absorption as judged by fasting serum carotene levels and urinary excretion of $\mathrm{D}$-xylose after a $10 \mathrm{~g}$ oral dose. Absorption of dietary fat was normal in each of the four subjects studied by fecal fat measurement in 72-hr stool specimens, and prothrombin activity was normal in the three subjects tested. All patients were maintaining stable weights, and none complained of nausea, vomiting, anorexia, diarrhea, or recent weight loss. Case No. 4 had mild maturity onset diabetes controlled by diet. The clinical and laboratory features are summarized in Table I. All studies were carried out under metabolic ward conditions which ensured careful and complete collection of specimens. Informed consent was given by all participants after the nature of the investigations was explained in detail.
The tests of folate- ${ }^{14} \mathrm{C}$ absorption were carried out in the mornings with patients in the fasting state. Base line blood and urine samples were obtained before oral administration of the test compound. Heparinized venous blood samples were obtained at hourly intervals for $4 \mathrm{hr}$ thereafter, and daily 24-hr specimens of stool and urine were collected. A light lunch consisting of gelatin and a soft drink was given at the end of $4 \mathrm{hr}$. The evening meal consisted of a serving of rice and two frankfurters sliced lengthwise in quarters. These had been thrice boiled in a large volume of water which was discarded, as described by Herbert (9), in order to minimize the intake of dietary folate during the 1st 24-hr test period. The regular hospital diet was consumed thereafter. Complete collections of exhaled air were obtained in a 200 liter Douglas bag for $30 \mathrm{~min}$ and $25 \mathrm{~min}$, respectively, in two patients.

${ }^{14} \mathrm{C}$-labeled polyglutamates were synthesized as described elsewhere (reference 10, footnote 1). Minor contaminants were removed by chromatography on diethylaminoethyl (DEAE)-cellulose columns. Doses were calculated on the basis of molar extinction coefficients of the purified product. Folic acid-2- ${ }^{14} \mathrm{C}$ was obtained commercially ${ }^{2}$ and similarly purified before use. This material was also used as a source of pteroic acid-2-14C which was coupled to heptaglutamate yielding ring-labeled pteroylheptaglutamate for administration to the first patient. Synthetic polyglutamate compounds were prepared so as to provide approximately $1 \mu \mathrm{c} / \mu$ mole; the monoglutamate was given in a solution containing approximately $2 \mu \mathrm{c} / \mu \mathrm{mole}$. The first patient received $1.0 \mu \mathrm{mole}$ of folate; all subsequent subjects received $10.0 \mu$ mole of folate.

The second subject also received pteroylheptaglutamate. However, in this case the compound was produced by coupling nonradioactive pteroic acid to a seven unit gamma polyglutamate in which the $N$-terminal amino acid was glutamic acid-UL- ${ }^{14} \mathrm{C}$. A molecule of heptaglutamate labeled in the glutamate of the folic acid molecule with six additional nonradioactive glutamates in the chain is thus obtained.

\footnotetext{
${ }^{1}$ Krumdieck, C., and C. M. Baugh. 1969. The solid phase synthesis of polyglutamates of folic acid. Biochemistry. Manuscript submitted for publication.

' Nuclear-Chicago Corporation, Des Plaines, Ill.
}

TABLE I

Summary of Clinical and Laboratory Data of Patients under Invesiigation

\begin{tabular}{|c|c|c|c|c|c|c|c|c|c|c|}
\hline $\begin{array}{c}\text { Patient } \\
\text { No. }\end{array}$ & Age & Sex & Diagnosis & $\begin{array}{l}\text { Enlargement of } \\
\text { lymph nodes, liver, } \\
\text { and spleen }\end{array}$ & WBC & $\mathrm{PCV}$ & $\begin{array}{l}\text { Urine, xylose } \\
\text { excretion* }\end{array}$ & Fecal fatł & $\begin{array}{l}\text { Fasting serum } \\
\text { carotene }\end{array}$ & $\begin{array}{l}\text { Prothrombin } \\
\text { activity }\end{array}$ \\
\hline & & & & & per $m m^{8}$ & $\%$ & $\mathrm{~g} / 5 \mathrm{hr}$ & $\mathrm{g} / 24 \mathrm{hr}$ & $\mu g / 100 \mathrm{ml}$ & \\
\hline 1 & 63 & M & CLL & + & 12,100 & 39 & 2.0 & 2.52 & 229 & $>90 \%$ \\
\hline 2 & 31 & $F$ & HD & 0 & 5,700 & 41 & 3.3 & 3.86 & 98 & $>90 \%$ \\
\hline 3 & 81 & $\mathrm{~F}$ & CLL & ++ & 19,400 & 41 & 2.2 & - & 124 & - \\
\hline 4 & 65 & F & CLL & + & 27,500 & 37 & 2.9 & 1.12 & 217 & - \\
\hline 5 & 47 & $\mathbf{M}$ & CLL & ++ & 139,000 & 31 & 2.9 & 2.25 & 96 & $>90 \%$ \\
\hline \multicolumn{5}{|c|}{ Normal values } & $\begin{array}{c}5,000 \\
10,000\end{array}$ & $\begin{array}{r}M: 40-54 \\
F: 37-47\end{array}$ & $>1.5$ & $<7.2$ & $80-400$ & $>70 \%$ \\
\hline
\end{tabular}

WBC, white blood count; PCV, packed cell volume; CLL, chronic lymphatic leukemia; HD, Hodgkin's disease.

* The xylose test was based on a $10 \mathrm{~g}$ oral dose.

$¥$ The fecal fat was based on a 3 day collection while the patient consumed over $50 \mathrm{~g}$ of dietary fat daily.

1132 C. E. Butterworth, Jr., C. M. Baugh, and C. Krumdieck 
Each of the next two subjects received pteroylglutamyl$\boldsymbol{\gamma}$-glutamyl- $\boldsymbol{\gamma}$-glutamate synthesized with glutamate-UL- ${ }^{14} \mathrm{C}$ in the middle position. The final patient received columnpurified folic acid-2- ${ }^{14} \mathrm{C}$ diluted with purified nonradioactive folic acid in order to produce a specific activity of $4.6 \times 10^{6}$ $\mathrm{dpm} / \mu$ mole.

All radioactivity determinations were made on an automatic liquid scintillation counter (Nuclear-Chicago Corporation, Des Plaines, Ill.) with appropriate quenching curves and an accumulation of statistically significant counts. Plasma radioactivity measurements were made on filtrates after precipitation of protein by $10 \%$ trichloroacetic acid. Unaltered urine was added to the scintillation liquid.

Stool specimens were prepared for counting by homogenizing the $24 \mathrm{hr}$ specimens in $500 \mathrm{ml}$ of $0.05 \mathrm{~N} \mathrm{NaOH} .10 \mathrm{ml}$ of this homogenate, $15 \mathrm{ml}$ of saturated $\mathrm{KMnO}_{4}$, and $5 \mathrm{ml}$ of $1 \mathrm{~N} \mathrm{NaOH}$ were heated together in a boiling water bath for $20 \mathrm{~min}$. The excess permanganate was destroyed by the addition of ethanol dropwise. The suspension was cooled and filtered to remove $\mathrm{MnO}_{2}$. The solid was washed with water on the funnel; the clear, colorless filtrate was then adjusted to $\mathrm{pH} 7.0$ and its volume adjusted to $50 \mathrm{ml}$ with water. Aliquots of $0.5-1.0 \mathrm{ml}$ were counted. This simplified procedure was found to give identical results with a method involving complete oxidation using concentrated sulfuric acid and hydrogen peroxide and trapping of $\mathrm{O}_{2^{-}}{ }^{14} \mathrm{C}$ by bubbling through $\mathrm{NaOH}$.

The breath samples were quantitated by conversion of the $\mathrm{CO}_{2}$ to $\mathrm{BaCO}_{3}$. The expired air from the Douglas bag was pulled through a $1 \mathrm{~N}$ solution of $\mathrm{NaOH}$. To this solution was added an excess of $\mathrm{Ba}(\mathrm{OH})_{2}$. The resulting $\mathrm{BaCO}_{3}$ was collected by filtration, washed thoroughly with water, then ethanol, and dried in vacuo over $\mathrm{PO}_{5}$ at $100^{\circ} \mathrm{C}$. The $\mathrm{BaCO}_{3}$ was quantitated gravimetrically and counted as a suspension in Cab-O-Sil (Cabot Corporation, Oxides Division, Boston, Mass.) (11).

Microbiological assays were carried out with Streptococcus fecalis and Lactobacillus casei according to standard methods previously described (7).

\section{RESULTS}

The results are summarized in Tables II, III, and IV and in Figs. 1-5.
Pteroylheptaglutamate. The first patient to be studied received pteroylheptaglutamate labeled in position two of the pteridine ring, in a total oral dose of $1.0 \mu$ mole, equivalent to $441 \mu \mathrm{g}$ of pteroylglutamic acid. At this low dose it was not possible, with the quantity of plasma available, to demonstrate any change in $S$. fecalis activity or radioactivity, although plasma $L$. case $i$ values rose slightly from a base line value of 8.0 to $13.2 \mathrm{ng} / \mathrm{ml}$ as shown in Fig. 1. Stool collections on 3 consecutive days yielded a total of $50.8 \%$ of the administered dose, most of it on the 2nd day, and virtually none on the 4th day. The urine excreted during the 1 st $24 \mathrm{hr}$ contained $1.5 \%$ of the administered radioactivity. After this experience it was decided to use $10-\mu$ mole doses in subsequent tests.

The second patient received $10 \mu$ moles of pteroylheptaglutamate labeled in the glutamate unit attached to the pteroyl moiety. Microbiological and radioactivity curves of plasma are shown in Fig. 2. Calculations indicate that the specific radioactivity of the $1 \mathrm{hr}$ plasma (L. case $i$ folate) is $2.1 \times 10^{\circ} \mathrm{dpm} / \mu$ mole. A 3 day stool collection yielded $25.3 \%$ of the dose, while urine contained $8.0 \%$. The details of urinary folate and radioactivity excretion are presented in Table III. It may be seen that there is rather close agreement between the $L$. case $i$ folate value and the radioactivity determination. However the $S$. fecalis-active material represents only one-third of the $L$. case $i$ value, suggesting that the other two-thirds is in a form such as $N^{5}$-methyltetrahydrofolate which is active only for $L$. casei. When the $L$. casei value was used, the specific activity of the urinary folate is $1.65 \times 10^{\circ} \mathrm{dpm} / \mu \mathrm{mole}$, a value in rather close agreement with the specific activity of the dose, $1.96 \times 10^{\circ}$ $\mathrm{dpm} / \mu$ mole. This result indicates that there has been very little displacement of nonradioactive folate from tissues and suggests that metabolic conversion of radioactive folate has occurred producing forms not "seen"

TABLE II

Summary of Absorption and Excretion Data in Patients after Ingestion of ${ }^{14} \mathrm{C}$-Labeled Folate and Folylpolyglutamates

\begin{tabular}{|c|c|c|c|c|c|c|c|c|c|c|}
\hline \multirow[b]{2}{*}{ Patient } & \multirow[b]{2}{*}{ Diagnosis } & \multirow[b]{2}{*}{ Compound } & \multirow[b]{2}{*}{ Dose } & \multirow{2}{*}{$\begin{array}{c}\text { Folate } \\
\text { equivalent }\end{array}$} & \multirow{2}{*}{$\begin{array}{l}\text { Peak } \\
\text { plasma } \\
\text { folate } \\
\text { value } \\
\text { L. casei }\end{array}$} & \multicolumn{3}{|c|}{ dpm lost } & \multirow{2}{*}{$\begin{array}{l}\text { Biological } \\
\text { activity } \\
\text { lost, urine } \\
\text { L. casei }\end{array}$} & \multirow{2}{*}{$\begin{array}{l}\text { Estimated } \\
\text { net folate } \\
\text { retention }\end{array}$} \\
\hline & & & & & & Urine & Feces & Breath & & \\
\hline & & & umoles & $m g$ & $n g / m l$ & & $\%$ of dose & & $\mu g / 24 \mathrm{hr}$ & \% of dose \\
\hline G. J. & CLL & $\mathrm{Pt}^{*}(\mathrm{Glu})_{7}$ & 1 & 0.441 & 13 & 1.5 & 50.8 & - & - & 47.7 \\
\hline M. A. & HD & Pt Glu* - (Glu $)_{6}$ & 10 & 4.41 & 49 & 8.0 & 25.3 & - & 8.7 & 66.7 \\
\hline N. C. & CLL(1) & Pt Glu - Glu* - Glu & 10 & 4.41 & 20 & 0 & 0 & - & $<1.0$ & $?$ \\
\hline V.S. & CLL & Pt Glu - Glu* - Glu & 10 & 4.41 & 274 & 0 & 2.5 & $60 \%+$ & 60 & 37.5 \\
\hline R. B. & CLL & $\mathrm{Pt}^{*}-\mathrm{Glu}$ & 10 & 4.41 & 200 & 44 & 10 & 0 & 50 & 46 \\
\hline
\end{tabular}

* Indicates location of ${ }^{14} \mathrm{C}$ label; $\mathrm{Pt}$, pteroyl; (1), folate deficient; plasma folate $=0.62 \mathrm{ng} / \mathrm{ml}$ and $0.85 \mathrm{ng} / \mathrm{ml}$ on two separate occasions before test. (Normal range $=2.0-10.4 \mathrm{ng} / \mathrm{ml}$.) 


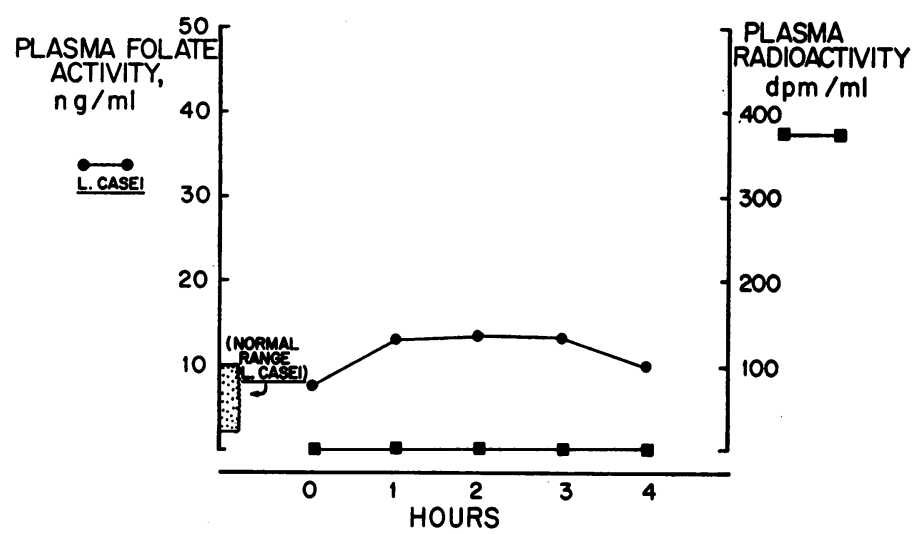

FIgURE 1 (Patient No. 1). The curves of plasma radioactivity and L. casei folate activity after ingestion of pteroylheptaglutamate-2- ${ }^{14} \mathrm{C}$ are presented. (In this Figure and in all other Figures, asterisks after compounds indicate radioactivity.) A total dose of $1 \mu$ mole, equivalent to $441 \mu \mathrm{g}$ of folic acid was administered. Because of the small size of the plasma samples, it was not possible to detect changes in radioactivity. For this reason the radioactivity curve is shown as a flat line, although in fact plasma samples may have contained radioactivity. The urine specimens collected during the $24 \mathrm{hr}$ after the dose contained $1.5 \%$ of the radioactivity administered, and the feces collected for 3 days contained $50.8 \%$ of the radioactivity.
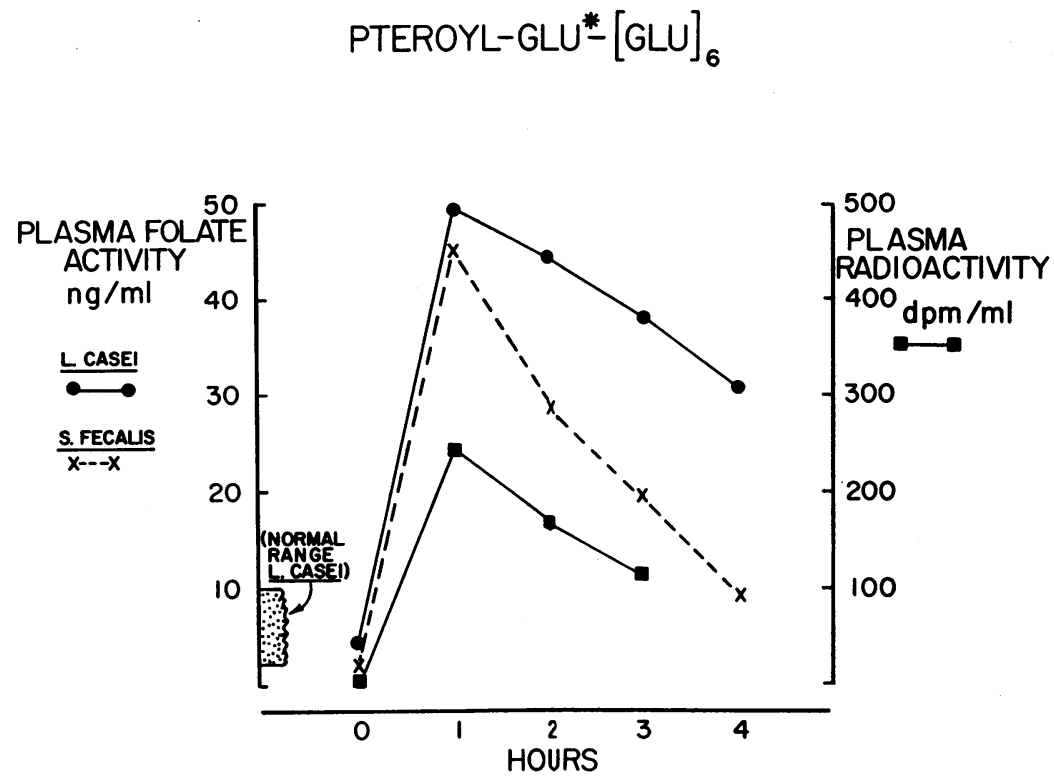

FIgURE 2 (Patient No. 2). Curves of radioactivity and microbiological folate activity after the ingestion of $10 \mu$ moles of pteroyl-UL-14 C-glutamyl- $\gamma$-hexaglutamate. The specific radioactivity of plasma folate at $1 \mathrm{hr}$ is $2.12 \times 10^{6} \mathrm{dpm} /$ $\mu$ mole which compares favorably with the specific radioactivity of the dose, $1.96 \times 10^{8} \mathrm{dpm} / \mu$ mole. The more rapid decline of activity for $S$. fecalis than for $L$. casei in the later samples is compatible with conversion of a portion of the labeled folate to a form such as $N^{5}$-methyltetrahydrofolate. This relationship was also observed in the $24 \mathrm{hr}$ urine which contained $7.6 \%$ of the radioactive dose, most of it in an $L$. casei-active form. A total of $25.3 \%$ of the radioactivity was recovered in the feces over a 3 day period. 
TABLE III

Sequential Changes in Urinary Folate and Radioactivity after Ingestion of Pteroylheptaglutamate (Case No.2)

\begin{tabular}{|c|c|c|c|c|c|c|c|}
\hline \multirow{3}{*}{ Date } & \multirow{3}{*}{ Oral folate dose } & \multicolumn{6}{|c|}{ 24-hr urine } \\
\hline & & \multicolumn{2}{|c|}{ S. fecalis } & \multicolumn{2}{|c|}{ L. casei } & \multicolumn{2}{|c|}{ Radioactivity } \\
\hline & & $\mu g$ & $\%$ of dose & $\mu g$ & $\%$ of dose & $d p m$ & $\%$ of dose \\
\hline $13-14$ & None & 2.4 & & 10.2 & & 0 & 0 \\
\hline & $\begin{array}{l}10 \mu \text { moles pteroyl-UL-14 } \mathrm{C} \text { - } \\
\text { glutamyl- } \gamma \text {-hexaglutamate, } \\
4.41 \mathrm{mg} ; 1.96 \times 10^{6} \mathrm{dpm} / \mu \text { mole }\end{array}$ & 123.7 & 3.0 & $396.0^{*}$ & 8.7 & $1,492,590$ & 7.60 \\
\hline $15-16$ & None & 4.6 & & 11.1 & & 77,390 & 0.40 \\
\hline $16-17$ & None & 5.7 & & 26.5 & & 4,900 & 0.04 \\
\hline $17-18$ & None & 10.7 & & 19.5 & & 0 & 0 \\
\hline $18-19$ & $20 \mathrm{mg}$ PGA & 3699.0 & 18.5 & 5240.0 & 26.0 & 53,600 & 0.3 \\
\hline $19-20$ & None & 3.5 & & 21.6 & & & \\
\hline
\end{tabular}

PGA, pteroylglutamic acid.

* Specific radioactivity of urinary $L$. casei folate is $1.65 \times 10^{6} \mathrm{dpm} / \mu$ mole.

by $S$. fecalis. Since urinary folates are said to be primarily in the monoglutamate form (see Discussion, below), conversion to $N^{\mathrm{s}}$-methyltetrahydrofolate seems likely. Table III also indicates failure of a large folate dose (20 mg given orally) to displace previously administered radioactive folate. This observation tends to confirm the impression noted above that incoming folate produces little, if any, displacement of other folate forms from tissue depots.

Pteroylglutamyl- ${ }^{2}{ }^{1} C$-glutamyl- $\gamma$-glutamate. The third patient was found, unexpectedly, to have abnormally low serum $L$. case $i$ folate values on two separate specimens before the test. This was an $81 \mathrm{yr}$ old widow living on a low income, so that an early dietary deficiency is thought to be the most likely explanation. After ingestion of 10 $\mu$ moles of pteroyltriglutamate labeled in the middle glutamic acid moiety, the maximum rise in serum $L$. case $i$ activity was to $20 \mathrm{ng} / \mathrm{ml}$. This flat curve is best explained by rapid removal from the circulation to replete tissue stores. However, there was an additional unexpected finding: no significant counts above background radioactivity could be detected in plasma, urine, or feces. In order to account for the administered label, it was decided to collect breath and look for $\mathrm{O}_{2}{ }^{14} \mathrm{C}$ in the expired air.

In the fourth patient, who also received $10 \mu$ moles of the middle-labeled triglutamate, breath was collected for a $30 \mathrm{~min}$ period in addition to the usual specimens of blood, urine, and feces. Furthermore, a $200 \mathrm{ml}$ plasma sample was obtained by plasmapheresis over a period from 50 to $70 \mathrm{~min}$ after ingestion of $10 \mu$ moles of the "middle-labeled" triglutamate. The red cells were returned to the patient. Protein was precipitated from 100 $\mathrm{ml}$ of plasma, and the supernatant was passed through a DEAE-cellulose column. The folate was eluted and proved to be entirely devoid of radioactivity. Similarly, the folate recoverable by adsorption to and elution from charcoal was nonradioactive at each hourly sample.

TABLE IV

Sequential Changes in Urinary Folate and Radioactivity after Ingestion of Pteroylglutamate-2-14C (Case No. 5)

\begin{tabular}{|c|c|c|c|c|c|c|c|}
\hline \multirow{3}{*}{ Date } & \multirow{3}{*}{ Oral folate dose } & \multicolumn{6}{|c|}{ 24-hr urine } \\
\hline & & \multicolumn{2}{|c|}{ S. fecalis } & \multicolumn{2}{|c|}{ L. casei } & \multicolumn{2}{|c|}{ Radioactivity } \\
\hline & & $\mu g$ & $\%$ of dose & $\mu g$ & $\%$ of dose & $d p m$ & $\%$ of dose \\
\hline $16-17$ & & 3.2 & & 5.7 & & 0 & 0 \\
\hline $17-18$ & $\begin{array}{c}10 \mu \text { moles pteroylglutamate }-2{ }^{14} \mathrm{C} \\
4.41 \mathrm{mg} ; 4.6 \times 10^{6} \mathrm{dpm} / \mu \text { mole }\end{array}$ & 2320.0 & 52.6 & $2205.0^{*}$ & 50.0 & $19,538,400$ & 42.4 \\
\hline $18-19$ & & 3.7 & & 10.5 & & 272,976 & \\
\hline $19-20$ & & 3.2 & & 10.0 & & 111,760 & \\
\hline $20-21$ & & 5.0 & & 5.8 & & 56,244 & \\
\hline $21-22$ & & - & & 8.9 & & 0 & \\
\hline
\end{tabular}

* Specific radioactivity $=3.91 \times 10^{8} \mathrm{dpm} / \mu$ mole. 


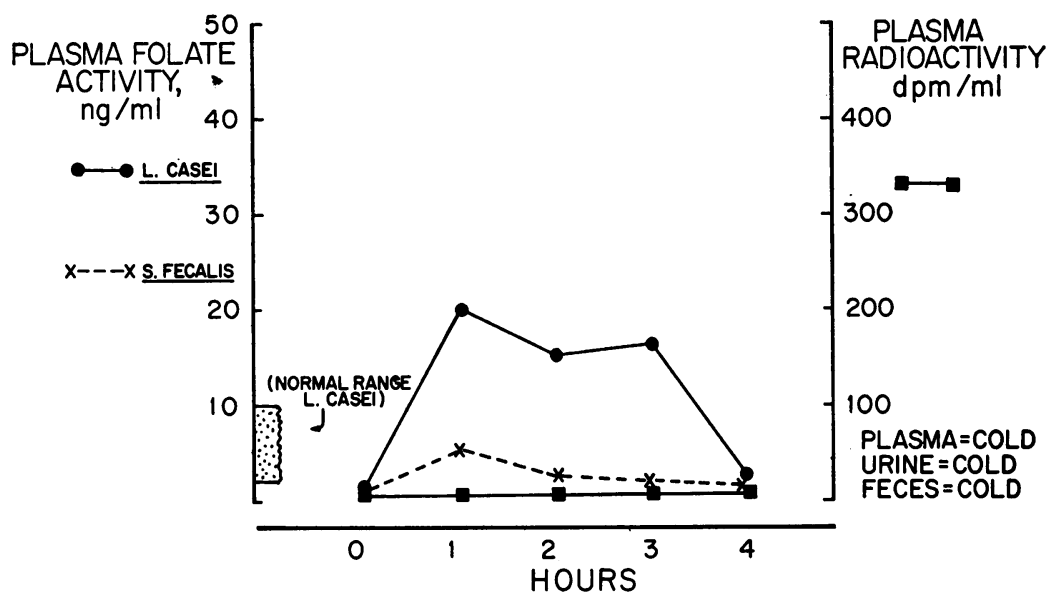

FIgURe 3 (Patient No. 3). Plasma microbiological folate activity and radioactivity curves observed after the ingestion of pteroylglutamyl- $\gamma$-UL-14 $\mathrm{C}$-glutamyl-r-glutamate. Calculations indicate that, in contrast with Fig. 1, the plasma samples would have been adequate to yield statistically significant counts of radioactivity if present. However, no radioactivity was detectable. Urine and feces likewise yielded no radioactivity. Base line folate values, which become available after the test, proved to be subnormal. Rapid clearance from the plasma of absorbed folate by deficient tissue is thought to be the most likely explanation of the flat absorption curve. The radioactivity cannot be accounted for (see Fig. 4).

However, carbon dioxide, recovered from the breath in $1 / 2 \mathrm{hr}$, contained $10 \%$ of the radioactivity administered. Since the breath was collected during the ascending portion of the blood absorption curve, it seems reasonable to assume that glutamic acid- ${ }^{14} \mathrm{C}$ became available for metabolism at an average rate approximating this value for at least $3 \mathrm{hr}$, and possibly 4 . Thus, an estimated $60-80 \%$ of the radioactivity could be accounted for in the breath. In any event only nonradioactive folate could be recovered from the plasma, a finding indicating complete dissociation between folic acid and the other two glutamate units. The feces contained only $2.5 \%$ of the radioactive dose, and the urine contained none. It should be pointed out that the chemical nature of the radioactivity in the stools was not established; it could represent unaltered pteroyltriglutamate or various derivatives of unabsorbed glutamic acid which had been released by enzymic cleavage. Although the possibility exists that the feces might contain an excess of free folic acid derived from the administered compound, this seems unlikely in view of the known efficient absorption of free folic acid (see below). For these reasons, the $2.5 \%$ figure may be considered only as a reasonable estimate for the fecal excretion of unabsorbed folate. The urine contained $2,676 \mu \mathrm{g}$ of $L$. case $i$-active folate, a finding indicating excretion of $60 \%$ of the dose as non- radioactive folate after it had been absorbed from the small intestine. On the basis of these fecal and urinary losses the net retention in this patient is estimated to be $37.5 \%$ of the dose, or $1.65 \mathrm{mg}$ of folic acid.

Pteroylglutamate. $-2{ }^{11} C$. The fifth patient received $10 \mu$ moles of purified free folate, labeled in the pteridine ring, for the purpose of comparing its absorption pattern with that observed in the preceding subject during absorption of folate derived by cleavage from triglutamate. The patterns of absorption were quite similar except that radioactivity accompanied the absorption and excretion of folate in this subject. Calculations indicate that the specific activity of plasma samples was $3.36 \times 10^{\circ} \mathrm{dpm} /$ $\mu$ mole compared with $4.60 \times 10^{\circ} \mathrm{dpm} / \mu$ mole of the dose. The specific activity of urinary folate was $3.90 \times 10^{\circ}$ $\mathrm{dpm} / \mu$ mole.

\section{DISCUSSION}

The results which have been presented demonstrate for the first time that ingested gamma polyglutamates of folic acid are cleaved to the monoglutamate form in man in the process of absorption. The site of cleavage cannot be stated with certainty, but it seems to occur at the time of intestinal absorption or very soon thereafter. The data indicate that when the ${ }^{14} \mathrm{C}$ label is in the first glutamate of the chain it remains firmly attached to the 


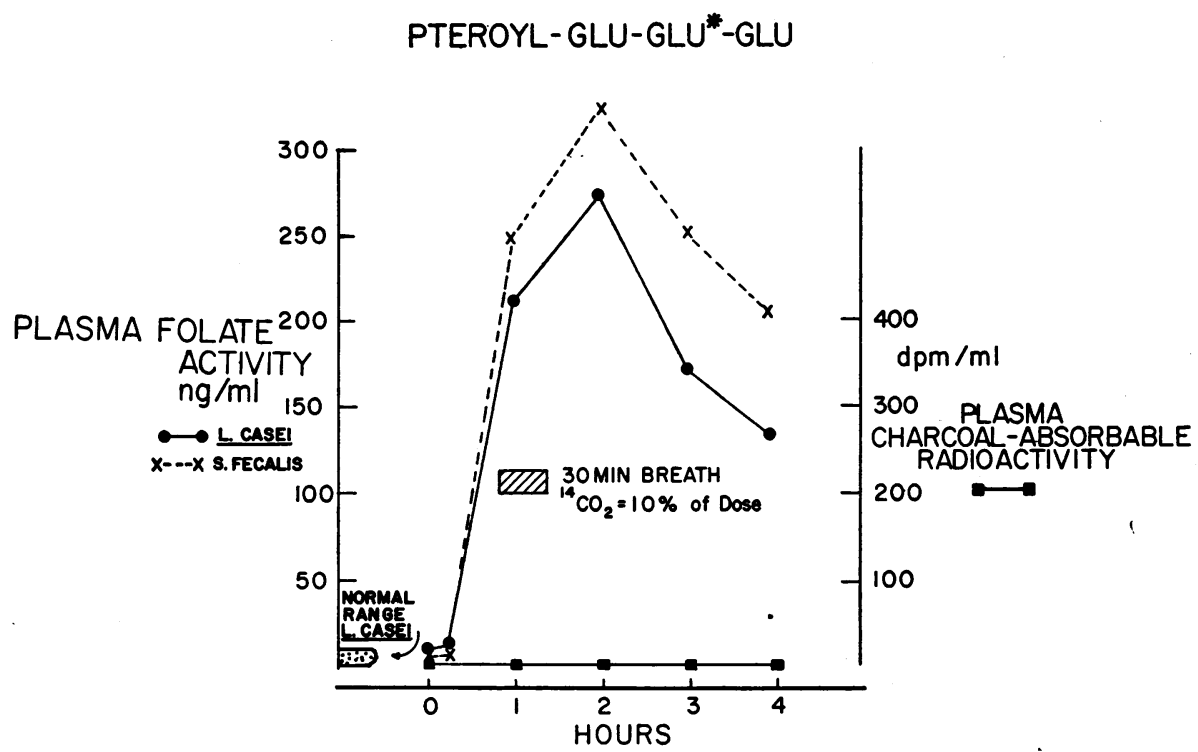

Figure 4 (Patient No. 4). Curves of radioactivity and microbiological folate activity in plasma at intervals after the ingestion of pteroylglutamyl- $\gamma-U L-{ }^{14} \mathrm{C}-$ glutamyl- $\gamma$-glutamate. As in the preceding patient, no significant radioactivity was detectable in plasma samples, and folate eluted after adsorption to charcoal was likewise nonradioactive. As a further check, folate was isolated from a $200 \mathrm{ml}$ sample of plasma obtained at $1 \mathrm{hr}$, by adsorption and elution from diethylaminoethyl (DEAE)-cellulose. Again the folate was devoid of radioactivity. However, breath collected from 50 to $80 \mathrm{~min}$ after ingestion of the dose contained $10 \%$ of the administered radioactivity, exhaled as carbon dioxide. This dissociation between radioactivity and microbiological folate activity is evidence that the administered molecule has been cleaved between the first and second glutamates, releasing unconjugated pteroylglutamate.

\section{PTEROYL $*$-GLU}

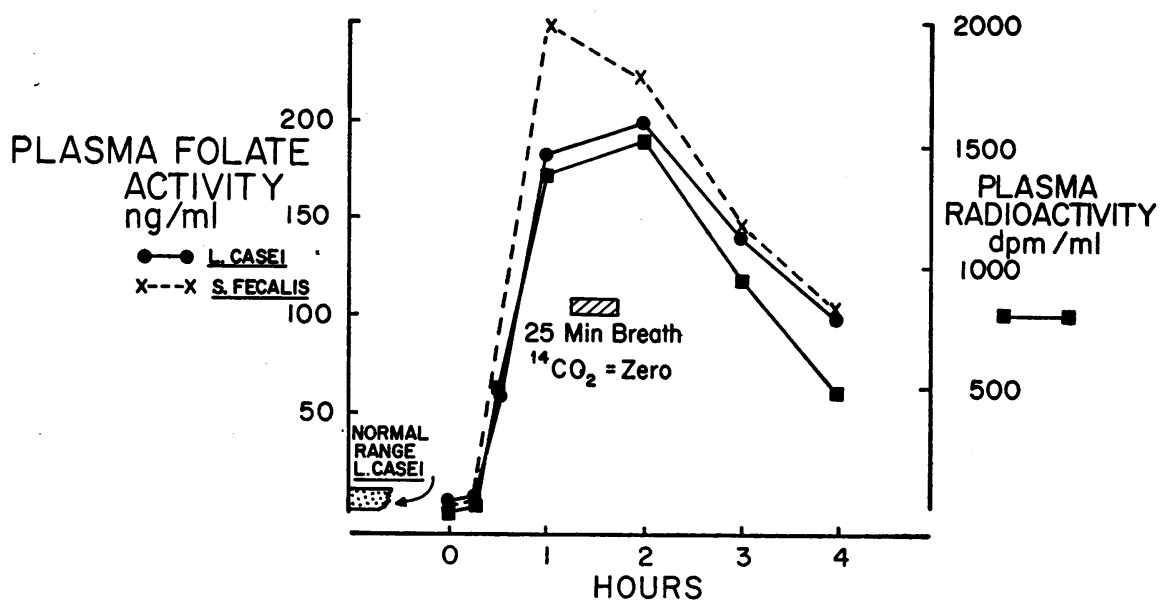

Figure 5 (Patient No. 5). Curves of radioactivity and microbiological folate activity in plasma after ingestion of folic acid-2- ${ }^{11} \mathrm{C}$. Note that radioactivity follows $L$. casei activity. The specific radioactivity of circulating folate at $1 \mathrm{hr}$ is $3.36 \times 10^{6} \mathrm{dpm} / \mu \mathrm{mole}$ while that of the dose was $4.6 \times 10^{\circ} \mathrm{dpm} / \mu$ mole (see text for further details). A breath sample revealed no radioactivity indicating no metabolic degradation of pteroylglutamate. 
pteroate moiety, since plasma radioactivity corresponds closely with plasma microbiological activity during the absorption period. Conversely, there is complete dissociation of radioactivity and microbiological folate activity of plasma when the ${ }^{16} \mathrm{C}$ label is in the second glutamate. In this situation a considerable portion of the administered label can be recovered promptly as $\mathrm{CO}$ s in the exhaled air, a finding suggesting that the free amino acid is liberated and fully oxidized to $\mathrm{CO}_{2}$ and $\mathrm{H}_{2} \mathrm{O}$.

There can be little doubt that man is capable of deriving his nutritional folate requirement from conjugated forms present in the diet. The amount of "free" folate which is available for assay in foods without conjugase treatment represents approximately one-fourth of the total and is probably inadequate of itself to meet nutritional requirements, particularly during pregnancy or periods of growth. On the other hand Baumslag and Metz (12) have reported that a large ration of raw lettuce containing little free folate is effective in the therapy of megaloblastic anemia of pregnancy. The importance of conjugated folates in the diet is further emphasized by evidence that diphenylhydantoin induces folate deficiency through a mechanism of conjugase inhibition in the gastrointestinal tract $(13,14)$. Compatible with this finding are the reports that small oral doses of free folate reverse the signs of megaloblastic anemia, although the anticonvulsant drug is continued (15). The present studies indicate that $50-70 \%$ of ingested folylheptaglutamate is "available" to man inasmuch as it is not lost in the feces. For this reason it would seem desirable to include this fraction in calculations of human dietary requirements and not merely the amount measurable by assay without conjugase digestion as has been proposed (9).

The digestion of folylpolyglutmates has not been extensively studied in man. Santini, Berger, Berdasco, Sheehy, Aviles, and Davila (6) as well as Klipstein (16) have reported that intestinal juice from sprue patients and normal subjects converts inactive dietary precursors into a form which is active in supporting the growth of $S$. fecalis. Since it is established that $S$. fecalis responds equally to either pteroylglutamic acid or pteroylglutamyl- $\gamma$-glutamate (17), these observations do not reveal the end product of luminal folate digestion. In an early clinical study Suarez, Welch, Heinle, Suarez, and Nelson (18) demonstrated that pteroylheptaglutamate, in daily oral doses equivalent to $8.4 \mathrm{mg}$ of free folic acid, caused rapid clinical improvement in a patient with tropical sprue. It is now recognized that this dose greatly exceeds minimal daily requirements, and as Girdwood (19) has commented, "It seems unlikely ... that the patient with sprue could absorb folic acid conjugates normally while absorbing the 'free' folic acid itself badly." Nevertheless this study, like that of Baumslag and Metz
(12), indicates that man is capable of deriving biologically active folate from a source which is inert in microbiological assay systems.

Baker et al. (20) observed that the "unnatural" synthetic compound, pteroylglutamyl- $\alpha$-glutamic acid causes increased plasma $L$. case $i$ activity after oral administration but not by parenteral injection. Presumably the terminal glutamate is removed by $\alpha$-peptidases in the digestive tract since the original compound is inert in microbiological assay systems. Synthetic pterolyglutamyl$\gamma$-glutamyl- $\gamma$-glutamic acid was reported to produce a rise only in plasma $L$. casei activity after oral administration. The authors concluded that this triglutamate is absorbed as such and circulates unaltered because no change was observed in $S$. fecalis activity. However, their data are also compatible with absorption as a methyl-substituted folylmonoglutamate or displacement of such a compound from tissue stores. (The phenomenon of displacement will be discussed in further detail, below.) In the present study pteroyltriglutamate produced a rise in plasma activity for both $L$. case $i$ and $S$. fecalis, a finding indicating the presence of not more than two glutamates in the circulating folate. The radioactivity curves demonstrated loss of the two terminal glutamate units but do not rule out the possibility that nonradioactive diglutamate might have been reformed during absorption.

Streiff and Rosenberg (21) have reported that 8 of 11 subjects had malabsorption of a small oral dose of yeast folylpolyglutamate but normal absorption of free folate. They also suggested that mucosal cells of rat small intestine contain an enzyme which converts folylpolyglutamates to the monoglutamate form $(21,22)$. While this may indeed prove to be correct it was based on the erroneous assumption that $L$. case $i$ activity reflects only the presence of monoglutamates. It is known that this organism is capable of utilizing the diglutamyl and triglutamyl forms of folate as well as the monoglutamate $(20$, 23).

Enzymes capable of producing a microbiologically active product from folylpolyglutamates have been described in a variety of tissues and organs of the rat, hog, $\mathrm{dog}$, cow, rabbit, and chicken $(24,25)$, in almond meal (25), and in an extract of the Portuguese Man-O-War, Physalia physalis (26). Of these only the chicken pancreas enzyme has been carefully characterized. Pfiffner et al. $(3,27)$ classified it as a carboxypeptidase after showing that it did not attack the methyl ester of pteroylheptaglutamate. Laskowski, Mims, and Day (24) found that it is heat-labile and has a $\mathrm{pH}$ optimum of 8.0. Kazenko and Laskowski (28) utilized chemically defined substrates and enzymatically measured reaction products in their investigation of purified chicken pancreas conjugase. Glutamic acid was liberated from the $\gamma$-triglu- 
tamate of $p$-aminobenzoic acid, synthetic pteroyltriglutamate, and from natural "fermentation $L$. casei factor." However, it was never possible to recover more than one equivalent of glutamic acid per molecule of substrate. Glutamic acid was not liberated from any of four $\alpha$-linked dipeptides, nor from glutathione in which the single glutamate is linked through a $\gamma$-peptide bond. They concluded that the enzyme is a $\gamma$-carboxypeptidase requiring at least two terminal glutamic acid molecules in the peptide chain and producing a diglutamate as the end product. If human pancreatic conjugase functions like that of the chicken, then it becomes necessary to postulate the existence of a $\gamma$-diglutamyl conjugase in either the intestinal epithelium or liver. A critical review of the literature does not reveal that evidence suggesting the existence of such an enzyme in man has been demonstrated heretofore. There have been a number of references to the work of Bird et al. (2) in support of the concept that hog kidney extracts contain an enzyme which produces the free monoglutamate as the end reaction product. However this view was based on the conversion of inactive precursors into some form which was active in supporting the growth of $S$. fecalis. Reliable proof of chemical structure, such as that presented by Kazenko and Laskowski (28) for chicken pancreas enzyme, has not been available for the products of hog kidney enzyme or for enzymes derived from other sources. However, it should be noted that Bolinder, Widoff, and Ericson (29) have presented data based on chromatographic identification of split products which tend to support the view that one of the products of hog kidney conjugase is pteroylglutamic acid.

A number of authors have studied the intestinal absorption of synthetic folic acid using either nonradioactive folate detected microbiologically $(19,30-35)$, or tritiumlabeled folate detected by both microbiological assay and radioactivity measurement (36-38). Denko (31) observed peak blood levels in 1-2 hr after ingestion of folic acid followed by excretion in the urine of $35-75 \%$ of the $5.0 \mathrm{mg}$ dose. Similar results were reported by Chanarin, Anderson, and Mollin (33). Whitehead and Cooper (34) have recently reported that folic acid is capable of crossing the intestinal mucosa unaltered, since free folate was present in samples of portal blood after oral ingestion of folic acid. This finding was in contradiction to conclusions reached by Baker, Frank, and Sobotka (39) that a conjugating system may be necessary to convert folic acid into a triglutamate form in order to accomplish intestinal absorption. Although the data presented by Whitehead and Cooper suggest that folic acid is readily absorbable in the monoglutamate form, they do not reveal whether polyglutamates are necessarily cleaved to this form during intestinal absorption and do not exclude the possibility that ingested polyglutamates might be absorbed as the di- or triglutamate. The results presented above provide an answer to this possibility by indicating that hepta- and triglutamates pass through a monoglutamate phase in the process of absorption. The findings of Whitehead and Cooper (34), like those presented here, suggest that methylation and reduction of folic acid do not occur to any appreciable extent during its passage through the intestinal mucosa, but they do not exclude the possibility that $N^{5}$ or $N^{10}$-substituted folates could be absorbed from a polyglutamate precursor after suitable cleavage. In an extension of this work it was observed that after ingestion of folic acid, blood emerging from the hepatic vein was rich in $L$. casei-active material and low in $S$. fecalis activity (34). This was considered to be the result of displacement of $N^{5}$-methyltetrahydrofolate from the liver by incoming folic acid. Such an interpretation is compatible with the mechanism suggested earlier by Chanarin and McLean (40) who found only nonradioactive methylfolate in the urine of three out of four normal persons after parenteral administration of tritiated folate. Displacement studies have also been carried out by Johns, Sperti, and Burgen (41), Johns and Plenderleith (42), and Sheehy et al. (37). However, these studies suffer from the instability of the tritium label and the uncertainty as to its location, two major disadvantages which do not exist in the ${ }^{14} \mathrm{C}$-labeled material in the present study. The studies of Johns et al. (41) and Sheehy et al. (37) indicate that folate is not readily available for excretion if the flushing dose is given after a delay of 24 $\mathrm{hr}$. In the present study less than $1 \%$ of the radioactive dose could be displaced into the urine by a $20 \mathrm{mg}$ oral dose of nonradioactive folate given 4 days later.

Yoshino (43) has studied the absorption and excretion of tritiated folic acid in man. Nonfolate tritium was eliminated by recovering folate from specimens with carrier folate and DEAE-cellulose column chromatography. $\mathrm{He}$ reported a mean urinary excretion of $48.4 \%$ of the dose in $24 \mathrm{hr}$, and a mean $24-\mathrm{hr}$ fecal loss of $3.5 \%$. These values are in agreement with the findings in the one subject reported here who received folic acid-2- ${ }^{14} \mathrm{C}$. Yoshino also described diminished urinary folate excretion in certain malabsorption syndromes, pernicious anemia, and leukemia. Chronic lymphatic leukemia was not among the hematologic disorders studied.

The site and cellular mechanism of absorption of unconjugated folic acid in man were considered in the report by Hepner, Booth, Cowan, Hoffbrand, and Mollin (35). Small bowel perfusion was carried out with a double-lumen tube with separated orifices, various concentrations of free folate, and a nonabsorbable reference material. It was observed that the proximal small bowel is the principal site of folate absorption in normal persons, and that this function is impaired in celiac dis- 
ease. There was poor absorption in the distal jejunum and none in the ileum. It was further noted that folate disappeared from the lumen in one patient in spite of the fact that the serum folate had been elevated 30 -fold by an intravenous injection. Thus, absorption against a concentration gradient suggested an active transport mechanism which is capable of operating at a level vastly in excess of the physiological requirement. Cohen (44) has also suggested that folate absorption occurs by an active process. Yoshino (45) has also reported that the proximal small bowel is the principal absorption site for folic acid in the rat. While noting that it is difficult to deny the existence of an active transport system, he favored a passive transport mechanism. This view was based on evidence that neither metabolic inhibitors, folate antagonists, nor exogenous folate would prevent folate absorption, suggesting that if there is an active mechanism it has an extremely high capacity.

Pitney, Joske, and MacKinnon (46) have reported a high incidence of folic acid malabsorption among patients having malignant lymphoma, including eight patients with chronic lymphatic leukemia. However, their patient population also had a high incidence of sieatorrhea, subnormal serum carotene values, and abnormal results of xylose absorption tests, in striking contrast to the patients reported here. Pitney et al. did not consider that increased tissue requirement for folic acid, as described by Swendseid, Bethell, and Bird (47), was a satisfactory explanation for their results, since four patients with disseminated carcinoma revealed normal absorption curves. In the present study absorption patterns were comparable both in patients with lymphoid masses and without. Plasma curves of folate activity after an oral dose of $4.41-\mathrm{mg}$ equivalents were quite similar to published normal curves in three of our four subjects. The flat curve was observed in an elderly woman living on a low income who had subnormal base line values of serum folate, probably on a nutritional basis. Although it is recognized that retention of folate by lymphoid tissue may be a factor in the interpretation of our results, we do not consider it likely that lymphoma has altered the basic mechanism of polyglutamate digestion, or of folate absorption, transport, and excretion. Further observations on normal subjects will be needed to clarify these points.

In the present series calculations of specific radioactivity in the folate of plasma and urine do not suggest significant displacement of nonradioactive folate from tissue stores. After the administration of either folate$2-{ }^{14} \mathrm{C}$ or pteroylheptaglutamate labeled in the first glutamic acid unit, the specific activities of plasma and urine compared rather closely to those of the ingested material. One patient (case No. 2) revealed a higher urinary content of material active for $L$. case $i$ than for
S. fecalis (396 $\mu \mathrm{g}$ vs. $123 \mu \mathrm{g}$ ), suggesting metabolic conversion of labeled material to a form such as $N^{5}$-methyltetrahydrofolate before excretion. The subject who received folate- $2-{ }^{14} \mathrm{C}$ apparently excreted approximately half the ingested dose as unaltered folate, since the material was equally active for $L$. case $i$ and $S$. fecalis. The specific activity was $25 \%$ less than the calculated value in the plasma and $15 \%$ less in the urine. While this may indicate some dilution by displacement of nonradioactive folate from tissue, it does not approach the nearly complete displacement as described by Chanarin and McLean after parenteral administration of tritiated folate in normal subjects. Obviously further investigations will be needed to determine if this discrepancy might be due to differences in labeled folate, patient material, dosage, or route of administration.

The present studies indicate that fecal losses of folate tend to be greater as the length of the poly- $\gamma$-glutamyl side chain increases. Thus the fecal loss was 25 and $51 \%$, respectively, when folate was administered as the heptaglutamate, and $10 \%$ when administered as the monoglutamate. Conversely, urinary loss, as judged by both radioactivity determination and microbiological assay, was $8.7 \%$ or less with the heptaglutamate and 50 $60 \%$ with the mono- and triglutamate. These findings would be in keeping with the view that suitable cleavage must occur in order to permit absorption in the proximal small bowel. Recent observations of Matthews, Crampton, and $L$ is (48) are of interest in connection with the absorption of short chain glutamyl peptides of folic acid. These investigators have reported more rapid absorption of certain dipeptides than from the equivalent amount of free amino acid. These observations may prove to be significant in connection with the digestion of folic acid polyglutamates and active transport of folic acid.

\section{ADDENDUM}

Since preparation of this report a comparison has been made in the same person between the absorption of folate- $2{ }^{14} \mathrm{C}$ and pteroylglutamyl- $\gamma$-UL- ${ }^{14} \mathrm{C}$-glutamyl- $\gamma$-glutamate. The patient has homocystinuria and will be described in further detail in a separate report. As in the present study a significant percentage of the ${ }^{14} \mathrm{C}$ could be recovered as $\mathrm{CO}_{2}$ in the breath after ingestion of the triglutamate, but not with the ring-labeled material. After oral administration of folate$2-{ }^{14} \mathrm{C}$ only $3.5 \%$ of the dose could be recovered in the stools over a $72 \mathrm{hr}$ period.

\section{ACKNOWLEDGMENTS}

These investigations were supported by grant T67I from the American Cancer Society; by grant Nos. AM-08644 and AM-5526 from the National Institutes of Health, U. S. Public Health Service; by contract No. DA-49-193-MD-2299 from the Office of the Surgeon General, U. S. Army; and by Clinical Research Center Grant 2MO1-FR-3203, U. S. Public Health Service. 


\section{REFERENCES}

1. Binkley, S. B., O. D. Bird, E. S. Bloom, R. A. Brown, D. G. Calkins, C. J. Campbell, A. D. Emmett, and J. J. Pfiffner. 1944. On the vitamin $B_{c}$ conjugate in yeast. Science. 100: 36 .

2. Bird, O. D., S. B. Binkley, E. S. Bloom, A. D. Emmett, and J. J. Pfiffner. 1945. On the enzymatic formation of vitamin $B_{c}$ from its conjugate. J. Biol. Chem. 157: 413.

3. Pfiffner, J. J., D. G. Calkins, E. S. Bloom, and B. L. O'Dell. 1946. On the peptide nature of vitamin $B_{c}$ conjugate from yeast. 1946. J. Amer. Chem. Soc. 68: 1392.

4. Hutchings, B. L., E. L. R. Stokstad, J. H. Mowat, J. H. Boothe, C. W. Waller, R. B. Angier, J. Semb, and Y. SubbaRow. 1946. Degradation of the fermentation L. casei factor. Ann. N. Y. Acad. Sci. 48: 273.

5. Toepfer, E. W., E. G. Zook, M. L. Orr, and L. R. Richardson. 1951. Folic acid content of foods. U. S. Government Printing Office, Washington, D. C.

6. Santini, R., Jr., F. M. Berger, G. Berdasco, T. W. Sheehy, J. Aviles, and I. Davila. 1962. Folic acid activity in Puerto Rican foods. J. Amer. Diet. Ass. 41: 562.

7. Butterworth, C. E., Jr., R. Santini, Jr., and W. B. Frommeyer, Jr. 1963. The pteroylglutamate components of American diets as determined by chromatographic fractionation. J. Clin. Invest. 42: 1929.

8. Merrifield, R. B. 1963 . Solid phase peptide synthesis. I. The synthesis of a tetrapeptide. J. Amer. Chem. Soc. 85: 2149.

9. Herbert, V. 1963. A palatable diet for producing experimental folate deficiency in man. Amer. J. Clin. Nutr. 12: 17 .

10. Baugh, C. M., and C. L. Krumdieck. 1968. The solid phase synthesis of polyglutamates of folic acid. Fed. Proc. 27: 455. (Abstr.)

11. Ott, D. C., C. R. Richmond, T. T. Trujillo, and $H$. Foreman. 1959. Cab-O-Sil suspensions for liquid-scintillation counting. Nucleonics. 17: 106.

12. Baumslag, N., and J. Metz. 1964. Response to lettuce in a patient with megaloblastic anaemia associated with pregnancy. S. Afr. Med. J. 38: 611 .

13. Hoffbrand, A. V., and T. F. Necheles. 1968. Mechanism of folate deficiency in patients receiving phenytoin. Lancet. 2 : 528.

14. Rosenberg, I. H., R. R. Streiff, H. A. Godwin, and W. B. Castle. 1968. Impairment of intestinal deconjugation of dietary folate. Lancet. 2: 530 .

15. Druskin, M. S., M. H. Wallen, and L. Bonagura. 1962. Anticonvulsant-associated megaloblastic anemia. N. Engl. J. Med. 267: 483 .

16. Klipstein, F. A. 1967. Intestinal folate conjugase activity in tropical sprue. Amer. J. Clin. Nutr. 20: 1004.

17. Hutchings, B. L., J. H. Mowat, J. J. Oleson, E. L. R. Stokstad, J. H. Boothe, C. W. Waller, R. B. Angier, J. Semb, and Y. SubbaRow. 1947. Pteroylaspartic acid, an antagonist for pteroylglutamic acid. J. Biol. Chem. $170: 323$.

18. Suárez, R. M., A. D. Welch, R. W. Heinle, R. M. Suárez, Jr., and E. M. Nelson. 1946. Effectiveness of conjugated forms of folic acid in the treatment of tropical sprue. J. Lab. Clin. Med. 31: 1294.

19. Girdwood, R. H. 1953. A folic-acid excretion test in the investigation of intestinal malabsorption. Lancet. 2: 53 .

20. Baker, H., O. Frank, S. Feingold, H. Ziffer, R. A. Gellene, C. M. Leevy, and H. Sobotka. 1965. Amer. J. Clin. Nutr. 17: 88.
21. Streiff, R. R., and I. H. Rosenberg. 1967. Absorption of polyglutamic folic acid. J. Clin. Invest. 46: 1121.

22. Rosenberg, I. H., and R. R. Streiff. 1967. Intestinal folic acid conjugase. Gastroenterology. 52: 1117. (Abstr.)

23. Herbert, V., and R. Zalusky. 1962. Interrelations of vitamin $B_{12}$ and folic acid metabolism: folic acid clearance studies. J. Clin. Invest. 41: 1263.

24. Laskowski, M., V. Mims, and P. L. Day. 1945. Studies on the enzyme which produces the Streptococcus lactis $\mathrm{R}$ stimulating factor from inactive precursor substance in yeast. J. Biol. Chem. 157: 731.

25. Bird, O. D., B. Bressler, R. A. Brown, C. J. Campbell, and A. D. Emmett. 1945. The microbiological assay of vitamin $\mathrm{B}_{\mathrm{c}}$ conjugate. J. Biol. Chem. 159: 631.

26. Wittenberg, J. B., J. M. Noronha, and M. Silverman. 1962. Folic acid derivatives in the gas gland of Physalia physalis L. Biochem. J. 85: 9.

27. Pfiffner, J. J., D. G. Calkins, B. L. O’Dell, E. S. Bloom, R. A. Brown, C. J. Campbell, and O. D. Bird. 1945. Isolation of and antianemia factor (vitamin $\mathrm{B}_{\mathrm{c}}$ conjugate) in crystalline form yeast. Science. 102: 228.

28. Kazenko, A., and M. Laskowski. 1948. On the specificity of chicken pancreas conjugase $(\gamma$-glutamic acid carboxypeptidase). J. Biol. Chem. 173: 217.

29. Bolinder, A., E. Widoff, and L. E. Ericson. 1953. Enzymatical and chemical studies on factors related to folic and folinic acid. Ark. Kemi. 6: 487.

30. Bethell, F. H., M. E. Swendseid, O. D. Bird, M. C. Meyers, G. A. Andrews, and R. A. Brown. 1946. Observations on the utilization of folic acid (vitamin $B_{c}$ ) and vitamin $B_{c}$ conjugate by persons with pernicious anemia and macrocytic anemia following gastrectomy. Univ. Hosp. Bull. 12: 42.

31. Denko, C. W. 1951. Pteroylglutamic acid clearance in normal adults. J. Appl. Physiol. 3: 559.

32. Butterworth, C. E., Jr., H. Nadel, E. Pérez-Santiago, R. Santini, Jr., and F. H. Gardner. 1957. Folic acid absorption, excretion, and leukocyte concentration in tropical sprue. J. Lab. Clin. Med. 50: 673.

33. Chanarin, I., B. B. Anderson, and D. L. Mollin. 1958. The absorption of folic acid. Brit. J. Haematol. 4: 156.

34. Whitehead, V. M., and B. A. Cooper. 1967. Absorption of unaltered folic acid from the gastro-intestinal tract in man. Brit. J. Haematol. 13: 679.

35. Hepner, G. W., C. C. Booth, J. Cowan, A. V. Hoffbrand, and D. L. Mollin. 1968. Absorption of crystalline folic acid in man. Lancet. 2: 302.

36. Anderson, B., E. H. Belcher, I. Chanarin, and D. L. Mollin. 1960. The urinary and faecal excretion of radioactivity after oral doses of ${ }^{3} \mathrm{H}$-folic acid. Brit. J. Haematol. 6: 439.

37. Sheehy, T. W., R. Santini, Jr., R. Guerra, R. Angel, and I. C. Plough. 1963. Tritiated folic acid as a diagnostic aid in folic acid deficiency. J. Lab. Clin. Med. 61: 650 .

38. Klipstein, F. A. 1963. The urinary excretion of orally administered tritium-labeled folic acid as a test of folic acid absorption. Blood. 21: 626.

39. Baker, H., O. Frank, and H. Sobotka. 1964. Mechanisms of folic acid deficiency in nontropical sprue. J. Amer. Med. Ass. $187: 119$.

40. Chanarin, I., and A. McLean. 1967. Origin of serum and urinary methyltetrahydrofolate in man. Clin. Sci. 32: 57.

41. Johns, D. G., S. Sperti, and A. S. V. Burgen. 1961. The metabolism of tritiated folic acid in man. J. Clin. Invest. 40: 1684 . 
42. Johns, D. G., and I. H. Plenderleith. 1963. Folic aciddisplacement in man. Biochem. Pharmacol. 12: 1071.

43. Yoshino, T. 1968. The clinical and experimental studies on the metabolism of folic acid using tritiated folic acid. I. Absorption tests of tritiated folic acid in man. J. Vitaminol. (Osaka). 14: 21.

44. Cohen, N. 1965. Differential microbiological assay in study of folic acid absorption in vitro by everted intestinal sacs. Clin. Res. 13: 252. (Abstr.)

45. Yoshino, T. 1968. The clinical and experimental studies on the metabolism of folic acid using tritiated folic acid. II. The experimental studies on the absorption site and mechanism of tritiated folic acid in rats. J. Vitaminol. (Osaka). 14: 35 .

46. Pitney, W. R., R. A. Joske, and N. L. MacKinnon. 1960. Folic acid and other absorption tests in lymphosarcoma, chronic lymphocytic leukaemia, and some related conditions. J. Clin. Pathol. 13: 440.

47. Swendseid, M. E., F. H. Bethell, and O. D. Bird. 1951. The concentration of folic acid in leukocytes. Observations on normal subjects and persons with leukemia. Cancer Res. 11: 864.

48. Matthews, D. M., R. F. Crampton, and M. T. Lis. 1968. Intestinal absorption of peptides. Lancet. 2: 639. 